\title{
Characterization of soluble bromide measurements and a case study of BrO observations during ARCTAS
}

\author{
J. Liao ${ }^{1}$, L. G. Huey ${ }^{1}$, E. Scheuer ${ }^{2}$, J. E. Dibb ${ }^{1}$, R. E. Stickel ${ }^{1}$, D. J. Tanner ${ }^{1}$, J. A. Neuman ${ }^{3,4}$, J. B. Nowak ${ }^{3,4}$, S. Choi $^{1}$, \\ Y. Wang ${ }^{1}$, R. J. Salawitch ${ }^{5,6,7}$, T. Canty ${ }^{5}$, K. Chance $^{8}$, T. Kurosu ${ }^{8, *}$, R. Suleiman ${ }^{8}$, A. J. Weinheimer ${ }^{9}$, R. E. Shetter ${ }^{9}$,

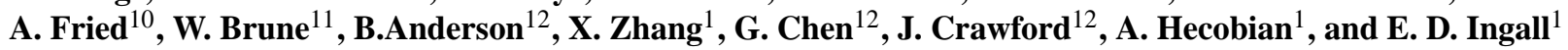 \\ ${ }^{1}$ School of Earth and Atmospheric Sciences, Georgia Institute of Technology, Atlanta, Georgia, USA \\ ${ }^{2}$ Institute for the Study of Earth, Oceans and Space, University of New Hampshire, Durham, NH, USA \\ ${ }^{3}$ Cooperative Institute for Research in Environmental Sciences, University of Colorado Boulder, Boulder, Colorado, USA \\ ${ }^{4}$ Earth System Research Laboratory, NOAA, Boulder, Colorado, USA \\ ${ }^{5}$ Department of Atmospheric and Oceanic Science, University of Maryland, College Park, Maryland, USA \\ ${ }^{6}$ Department of Chemistry and Biochemistry, University of Maryland, College Park, Maryland, USA \\ ${ }^{7}$ Earth System Science Interdisciplinary Center, University of Maryland, College Park, Maryland, USA \\ ${ }^{8}$ Harvard-Smithsonian Center for Astrophysics, Cambridge, MA, USA \\ ${ }^{9}$ Atmospheric Chemistry Division, National Center for Atmospheric Research, Boulder, Colorado, USA \\ ${ }^{10}$ Institute for Arctic and Alpine Research, University of Colorado, Boulder, CO, USA \\ ${ }^{11}$ Department of Meteorology, Pennsylvania State University, University Park, PA, USA \\ ${ }^{12}$ NASA Langley Research Center, Hampton, VA, USA \\ *now at: Jet Propulsion Laboratory, California Institute of Technology, Pasadena, CA, USA
}

Correspondence to: L. G. Huey (greg.huey@eas.gatech.edu)

Received: 17 August 2011 - Published in Atmos. Chem. Phys. Discuss.: 29 September 2011

Revised: 17 January 2012 - Accepted: 19 January 2012 - Published: 2 February 2012

\begin{abstract}
A focus of the Arctic Research of the Composition of the Troposphere from Aircraft and Satellites (ARCTAS) mission was examination of bromine photochemistry in the spring time high latitude troposphere based on aircraft and satellite measurements of bromine oxide $(\mathrm{BrO})$ and related species. The NASA DC-8 aircraft utilized a chemical ionization mass spectrometer (CIMS) to measure $\mathrm{BrO}$ and a mist chamber (MC) to measure soluble bromide. We have determined that the MC detection efficiency to molecular bromine $\left(\mathrm{Br}_{2}\right)$, hypobromous acid $(\mathrm{HOBr})$, bromine oxide $(\mathrm{BrO})$, and hydrogen bromide $(\mathrm{HBr})$ as soluble bromide $\left(\mathrm{Br}^{-}\right)$was $0.9 \pm 0.1,1.06+0.30 /-0.35,0.4 \pm 0.1$, and $0.95 \pm 0.1$, respectively. These efficiency factors were used to estimate soluble bromide levels along the DC-8 flight track of 17 April 2008 from photochemical calculations constrained to in situ BrO measured by CIMS. During this flight, the highest levels of soluble bromide and $\mathrm{BrO}$ were observed and atmospheric conditions were ideal for the spaceborne observation of $\mathrm{BrO}$. The good agreement $\left(R^{2}=0.76\right.$; slope $=0.95$; intercept $=-3.4 \mathrm{pmol} \mathrm{mol}^{-1}$ ) between modeled and observed soluble bromide, when $\mathrm{BrO}$ was above detection limit ( $>2 \mathrm{pmol} \mathrm{mol}^{-1}$ ) under unpolluted conditions
\end{abstract}

$\left(\mathrm{NO}<10 \mathrm{pmol} \mathrm{mol}^{-1}\right)$, indicates that the CIMS BrO measurements were consistent with the MC soluble bromide and that a well characterized MC can be used to derive mixing ratios of some reactive bromine compounds. Tropospheric $\mathrm{BrO}$ vertical column densities $\left(\mathrm{BrO}^{\mathrm{VCD}}\right)$ derived from CIMS $\mathrm{BrO}$ observations compare well with $\mathrm{BrO}_{\mathrm{TROP}}^{\mathrm{VCD}}$ from OMI on 17 April 2008.

\section{Introduction}

Tropospheric ozone depletion events (ODEs) have frequently been observed in or near the marine boundary layer in the Arctic (e.g. Oltmans, 1981; Bottenheim et al., 2009) and the Antarctic (e.g. Jones et al., 2009) during spring time. The ODEs can extend over horizontal scales of hundreds of kilometers (Ridley et al., 2003) and vertically from the surface to altitudes as high as several hundred meters to $\sim 1 \mathrm{~km}$ (Bottenheim et al., 2002; Ridley et al., 2003). In ODEs ozone mixing ratios drop from typical $30-40 \mathrm{nmol} \mathrm{mol}^{-1}$ to as low as $1 \mathrm{nmol} \mathrm{mol}^{-1}$ (e.g. Bottenheim et al., 2009 and 2002; Anlauf et al., 1994). During ODEs, bromine atoms can oxidize 
gaseous elemental mercury (GEM) to more active and soluble mercury compounds (e.g. Lindberg et al., 2002), which can deposit to the surface and become involved in biogeochemical cycles. The oxidation of certain volatile organic compounds (VOCs) can also be enhanced during ODEs (e.g. Jobson et al., 1994).

Field measurements (e.g. Barrie et al., 1988; Hausmann and Platt, 1994) and modeling results (e.g. Fan and Jacob, 1992; McConnell et al., 1992) have demonstrated that bromine chemistry plays a large role in ODEs. The mechanisms of bromine catalyzed ozone destruction are reviewed by Simpson et al. (2007) and the key reactions are listed below.

$$
\begin{aligned}
& \mathrm{Br}_{2}+h v \rightarrow 2 \mathrm{Br} \\
& \mathrm{Br}+\mathrm{O}_{3} \rightarrow \mathrm{BrO}+\mathrm{O}_{2} \\
& \mathrm{BrO}+\mathrm{BrO} \rightarrow 2 \mathrm{Br}+\mathrm{O}_{2} \\
& \mathrm{BrO}+\mathrm{HO}_{2} \rightarrow \mathrm{HOBr}+\mathrm{O}_{2} \\
& \mathrm{BrO}+\mathrm{NO} \rightarrow \mathrm{Br}+\mathrm{NO}_{2} \\
& \mathrm{BrO}+h v \rightarrow \mathrm{Br}+\mathrm{O} \\
& \mathrm{HOBr}+h v \rightarrow \mathrm{Br}+\mathrm{OH} \\
& \mathrm{Br}+\mathrm{CH}_{2} \mathrm{O} \rightarrow \mathrm{HBr}+\mathrm{HCO} \\
& \mathrm{Br}+\mathrm{HO}_{2} \rightarrow \mathrm{HBr}+\mathrm{O}_{2} \\
& \mathrm{HOBr}(\mathrm{aq})+\mathrm{Br}+\mathrm{H}^{+} \rightarrow \mathrm{Br}_{2}(\mathrm{aq})+\mathrm{H}_{2} \mathrm{O} \\
& \mathrm{BrO}+\mathrm{NO}_{2}+\mathrm{M} \rightarrow \mathrm{BrONO}_{2}+\mathrm{M}^{-} \\
& \mathrm{BrONO} \\
& 2
\end{aligned}
$$

Molecular bromine $\left(\mathrm{Br}_{2}\right)$ photolyzes and produces $\mathrm{Br}$ atoms at sunrise (Reaction R1). Ozone is destroyed by a catalytic cycle initiated by the reaction of $\mathrm{Br}$ with ozone $\left(\mathrm{O}_{3}\right)$, followed by the self-reaction of bromine oxide $(\mathrm{BrO})$ that regenerates $\mathrm{Br}$ atoms and destroys odd oxygen (Reactions R2 and R3). The efficiency of the cycle is suppressed by the conversion of bromine radicals to hydrogen bromide ( $\mathrm{HBr}$ ), which is soluble and therefore can deposit to aerosols or the surface (Evans et al., 2003). Hypobromous acid (HOBr), which is produced by the reaction of $\mathrm{BrO}$ and peroxyl radical $\left(\mathrm{HO}_{2}\right)$ (Reaction R4) as well as bromine nitrate $\left(\mathrm{BrONO}_{2}\right)$ hydrolysis (Reaction R12), can photolyze to produce $\mathrm{Br}$ atoms (Reaction $\mathrm{R} 7$ ) or react with $\mathrm{Br}^{-}$on surfaces to regenerate $\mathrm{Br}_{2}$ (Reaction $\left.\mathrm{R} 10\right)$ and sustain active bromine chemistry (Fan and Jacob, 1992). The most abundant daytime gasphase bromine species in the above mechanism, when ozone is above $1 \mathrm{nmol} \mathrm{mol}^{-1}$ in a typical Arctic environment (nitrogen dioxide $\left(\mathrm{NO}_{2}\right)<5 \mathrm{pmol} \mathrm{mol}^{-1}$ ), are $\mathrm{BrO}, \mathrm{HOBr}$ and $\mathrm{HBr}$ (e.g. Evans et al., 2003; Liao et al., 2011b). The most abundant night time species for these conditions is likely to be $\mathrm{Br}_{2}$ (Liao et al., 2011b).

Models incorporating bromine chemistry have been developed to simulate global ozone and mercury concentrations (e.g. Zeng et al., 2003; Holmes et al., 2010). However, the sources of active bromine in the atmosphere are not well quantified (e.g. Simpson et al., 2007 and references therein). Consequently, the bromine source is often parameterized in models or obtained from satellite observations of $\mathrm{BrO}$ (e.g. Fan and Jacob, 1992; Zeng et al., 2003). However, there are challenges deriving the tropospheric column $\mathrm{BrO}$ from satellite observations, which are obtained by subtracting the stratospheric contribution from a retrieval of total column BrO. Basic efforts at inferring tropospheric column BrO have assumed the stratospheric contribution is zonally symmetric. However, Theys et al. (2009) showed that the stratospheric burden of total bromine exhibits strong zonal asymmetries at high latitudes, particularly during spring. In addition, Salawitch et al. (2010) demonstrated the sensitivity of tropospheric column $\mathrm{BrO}$ inferred from satellites to zonal asymmetries in the satellite burden. Another issue is the impact of clouds on the calculation of air mass factors (AMFs) and the retrieval processes for the altitudes below the clouds (Kühl et al., 2008; Theys et al., 2011; Choi et al., 2011). The validation of tropospheric column $\mathrm{BrO}$ inferred from satellite retrievals using in situ measurements of $\mathrm{BrO}$ is an important research task, which we also address below.

The Arctic Research of the Composition of the Troposphere from Aircraft and Satellites (ARCTAS) (Jacob et al., 2010) mission and the Aerosol, Radiation, and Cloud Processes affecting Arctic Climate (ARCPAC) study (Brock et al., 2011) in spring 2008 provided an excellent opportunity to validate satellite $\mathrm{BrO}$ observations with in situ measurements of bromine species. ARCTAS and ARCPAC both featured research flights in the Arctic using aircraft with large suites of instruments (Jacob et al., 2010; Brock et al., 2011). Both the NASA DC-8 and NOAA WP-3D were equipped with chemical ionization mass spectrometers (CIMS) capable of measuring $\mathrm{BrO}$ and $\mathrm{Br}_{2}+\mathrm{HOBr}$ (Neuman et al., 2010). The NASA DC-8 was also equipped with a mist chamber (MC) measuring soluble bromide. The MC soluble bromide measurement is the sum of all gas phase and particulate phase species that dissolve in aqueous solution to form $\mathrm{Br}^{-}$(Ridley et al., 2003; Dibb et al., 2010). This measurement has been used in several polar locations and has proved to be an excellent tracer for active bromine chemistry (Ridley et al., 2003). Results from ARCTAS and ARCPAC indicated that tropospheric $\mathrm{BrO}$ levels were often much smaller than those derived from satellite data, particularly for an assumption of a zonally symmetric stratospheric burden. Salawitch et al. (2010) showed that low in situ BrO concentrations and background, non depleted levels of $\mathrm{O}_{3}$ were often observed in the footprint of satellite $\mathrm{BrO}$ "hotspots", especially over Hudson Bay. They suggested this apparent discrepancy could be resolved if very short lived bromocarbons contribute 
large amounts of inorganic bromine to the lowermost stratosphere, leading to substantial $\mathrm{BrO}$ mixing ratios that could give elevated column $\mathrm{BrO}$ in regions of a low altitude (high pressure) tropopause. Neuman et al. (2010) analyzed a series of flights from ARCPAC and ARCTAS and showed that active bromine $\left(\mathrm{Br}_{2}+\mathrm{HOBr}\right.$ ) (up to $\sim 16 \mathrm{pmol} \mathrm{mol}^{-1}$ ) was often detected in the marine boundary layer but found relatively low levels of $\mathrm{BrO}$ (up to $\sim 4 \mathrm{pmol} \mathrm{mol}^{-1}$ ). The focus of this work is to investigate the ARCTAS DC-8 flight on 17 April 2008 when the highest $\mathrm{BrO}$ and soluble bromide levels were observed by CIMS and MC, respectively. The response of the $\mathrm{MC}$ to the most abundant bromine $\left(\mathrm{Br}_{2}, \mathrm{BrO}, \mathrm{HOBr}\right.$, and $\mathrm{HBr}$ ) species is quantified to allow a thorough comparison of CIMS and MC data. Column abundances are derived from the in situ data and compared to satellite observations.

\section{Methods}

\subsection{Mist chamber (MC) characterization}

The response of the $\mathrm{MC}$ to the abundant bromine species $\left(\mathrm{Br}_{2}, \mathrm{BrO}, \mathrm{HOBr}\right.$, and $\left.\mathrm{HBr}\right)$ was determined in a series of laboratory tests. A known amount of each species was quantitatively delivered to the $\mathrm{MC}$ inlet and the resulting mixing ratio of bromide was measured. In this manner the $\mathrm{MC}$ response factor per atom of bromine was measured. A CIMS was used to quantify the $\mathrm{Br}_{2}, \mathrm{HOBr}$ and $\mathrm{BrO}$ distribution delivered to the $\mathrm{MC}$. This was critical as $\mathrm{HOBr}$ and $\mathrm{BrO}$ could not be delivered to the $\mathrm{MC}$ in a pure form. In addition, as $\mathrm{HOBr}$ can readily convert to $\mathrm{Br}_{2}$ on surfaces, different inlet setups were used to investigate this issue.

\subsubsection{Chemical ionization mass spectrometer (CIMS)}

The CIMS is very similar to that used to measure $\mathrm{BrO}$, peroxy acyl nitrates (PANs), pernitric acid $\left(\mathrm{HO}_{2} \mathrm{NO}_{2}\right)$, and sulfur dioxide $\left(\mathrm{SO}_{2}\right)$ (Liao et al., 2011a; Slusher et al., 2004; Kim et al., 2007; Huey, 2007). The methods used to measure and calibrate the CIMS to $\mathrm{BrO}$ and $\mathrm{Br}_{2}$ are described in Liao et al. (2011a). Hydrated $\mathrm{I}^{-}$was utilized as a reagent ion to detect the bromine species and the corresponding reactions of the core ions are listed below;

$$
\begin{aligned}
& \mathrm{Br}_{2}+\mathrm{I}^{-} \rightarrow \mathrm{IBr}_{2}^{-} \\
& \mathrm{BrO}+\mathrm{I}^{-} \rightarrow \mathrm{IBrO}^{-} \\
& \mathrm{HOBr}+\mathrm{I}^{-} \rightarrow \mathrm{IHOBr}^{-}
\end{aligned}
$$

$\mathrm{I}^{-}$was chosen as a reagent ion because it can selectively and accurately detect $\mathrm{HOBr}, \mathrm{BrO}$, and $\mathrm{Br}_{2}$ (Liao et al., 2011a, b; Neuman et al., 2010). $\mathrm{SF}_{6}^{-}$was not used as a reagent ion in this study as it is not capable of selectively detecting $\mathrm{HOBr}$ (Huey et al., 1995). The accuracy of the $\mathrm{Br}_{2}, \mathrm{BrO}$ and $\mathrm{HOBr}$ measurements in the laboratory was estimated to be $7 \%, 32 \%$, and $32 \%$, respectively.

\subsubsection{Mist chamber (MC)}

The mist chamber, similar to that used to measure nitric acid $\left(\mathrm{HNO}_{3}\right)$ and other soluble species (e.g. Dibb et al., 1998), can detect soluble bromide $\left(\mathrm{Br}^{-}\right)$from source compounds in the gas phase and fine particulates in the sampled air. The soluble species were concentrated into a small volume of ultrapure water and the stripping solutions were analyzed by ion chromatography as $\mathrm{Br}^{-}$in the solution (Dibb et al., 1994). The $\mathrm{Br}^{-}$mixing ratio in the sampling gases was determined from the concentration of $\mathrm{Br}^{-}$in the solution, the solution volume and the gas flow rate to the MC. The measurement uncertainty for soluble bromide was $\sim \pm 15 \%$. The uncertainty represents a combination of accuracy and precision at the one sigma level.

\subsubsection{Experiment setup}

The CIMS and MC were operated simultaneously in the same laboratory (Fig. 1). Bromine compounds were delivered to both instruments through perfluoroalkoxy (PFA) Teflon tubing. In the initial experiments, setup A, a flow of nitrogen $\left(\mathrm{N}_{2}\right)$ at 3 standard liters per minute (slpm, standard temperature $=273 \mathrm{~K}$, standard pressure $=1.01 \times 10^{5} \mathrm{~Pa}$ ) containing bromine compounds was delivered to the inlets of the CIMS and the MC alternately with the same Teflon tubing. In later experiments, setup B, a 3 slpm flow containing bromine compounds was symmetrically divided with a PFA tee between the CIMS and MC. The length of the Teflon tubing from the $\mathrm{HOBr}$ source to the $\mathrm{MC}$ was $\sim 1.2 \mathrm{~m}$ longer than to the CIMS in setup B. As a consequence, any possible interactions of gas with the sampling line were the same in setup A for both instruments and were larger for the MC in setup B. Upon exiting the sample line, the gas flowed directly into the CIMS ion-molecule reaction tube (flow tube), where very little wall interaction and conversion of bromine species (e.g. $\mathrm{HOBr}$ to $\mathrm{Br}_{2}$ ) occur (Neuman et al., 2010). The potential interactions with other surfaces in the MC (e.g. the wetted glass walls of the mist chamber) may cause interconversion of bromine species. As setup B better represented the conversion of bromine compounds (e.g. $\mathrm{HOBr}$ ) on the sampling inlet of the $\mathrm{MC}$ on the $\mathrm{DC}-8$, the detection efficiencies of $\mathrm{HOBr}$ and $\mathrm{Br}_{2}$ from setup $\mathrm{B}$ are used to predict soluble bromide concentrations.

\subsection{4 $\mathrm{Br}_{2}$, BrO, HOBr and $\mathrm{HBr}$ preparation}

Pure gas phase $\mathrm{Br}_{2}$ was obtained from a permeation tube (Kin-tek Trace Source ${ }^{\mathrm{TM}}$ disposable permeation tube for bromine). 20 standard cubic centimeters per minute ( $\mathrm{sccm}$ ) of $\mathrm{N}_{2}$ continuously flowed over the $\mathrm{Br}_{2}$ permeation tube, which was held at a constant temperature $\left(40^{\circ} \mathrm{C}\right)$. $\mathrm{The}^{\mathrm{Br}} \mathrm{Br}_{2}$ permeation tube output was measured, by converting $\mathrm{I}^{-}$to $\mathrm{I}_{3}^{-}$ in aqueous solution (Liao et al., 2011a), to be $86 \pm 6 \mathrm{ng} \mathrm{min}^{-1}$ and $\sim 4 \mathrm{nmol} \mathrm{mol}^{-1}$ in $3 \mathrm{slpm} \mathrm{N}_{2}$ flow. 
$\mathrm{BrO}$ was generated by the reaction of $\mathrm{Br}_{2}$ with $\mathrm{O}\left({ }^{3} \mathrm{P}\right)$ in excess $\mathrm{O}_{3}$ (Liao et al., 2011a). $\mathrm{O}_{3}$ was produced by flowing 30 sccm of $\mathrm{O}_{2}$ through a quartz tube illuminated by a UV lamp. The $\mathrm{O}_{3}$ and $\mathrm{Br}_{2}$ were diluted in $\sim 1.5 \mathrm{slpm} \mathrm{N}_{2}$ and flowed through an oven. When the oven was heated to $\sim 350^{\circ} \mathrm{C}$, $\mathrm{BrO}$ was produced by the following series of reactions.

$\mathrm{O}_{3}+\mathrm{M} \rightarrow \mathrm{O}_{2}+\mathrm{O}\left({ }^{3} \mathrm{P}\right)+\mathrm{M}$

$\mathrm{Br}_{2}+\mathrm{O}\left({ }^{3} \mathrm{P}\right) \rightarrow \mathrm{BrO}+\mathrm{Br}$

$\mathrm{Br}+\mathrm{O}_{3} \rightarrow \mathrm{BrO}+\mathrm{O}_{2}$

The CIMS sensitivity ratio of $\mathrm{BrO}$ to $\mathrm{Br}_{2}$ was estimated to be $0.47 \pm 25 \%$, based on the amount of $\mathrm{BrO}$ synthesized and the amount of $\mathrm{Br}_{2}$ decomposed (Liao et al., 2011a).

Gas phase $\mathrm{HOBr}$ was prepared by adding 5-7 drops of liquid $\mathrm{Br}_{2}$ to silver nitrate $\left(\mathrm{AgNO}_{3}\right)$ aqueous solution $(2.2 \mathrm{~g}$ $\mathrm{AgNO}_{3}$ in $100 \mathrm{~mL}$ de-ionized $\mathrm{H}_{2} \mathrm{O}$ ) in a glass trap that was kept at $0{ }^{\circ} \mathrm{C}$ in the dark (Jin et al., 2007). The $\mathrm{AgNO}_{3}$ is used to precipitate out $\mathrm{Br}^{-}$as silver bromide (AgBr). This drives the equilibrium towards $\mathrm{HOBr}$ and reduces the degassing of $\mathrm{HBr}$ from the solution.

$$
\begin{aligned}
& \mathrm{Br}_{2}+\mathrm{H}_{2} \mathrm{O} \Leftrightarrow \mathrm{HOBr}+\mathrm{H}^{+}+\mathrm{Br}^{-} \\
& \mathrm{Ag}^{+}+\mathrm{Br}^{-} \rightarrow \mathrm{AgBr} \downarrow
\end{aligned}
$$

Gas phase $\mathrm{HOBr}$ and $\mathrm{Br}_{2}$ were removed from the trap in a flow of $\mathrm{N}_{2}(5-50 \mathrm{sccm})$. The resulting gas phase mixture of $\mathrm{HOBr}$ and $\mathrm{Br}_{2}$ was diluted into a $\mathrm{N}_{2}$ flow of $\sim 3$ slpm and used as a source of $\mathrm{HOBr}$. In general, the ratio of $\mathrm{HOBr}$ to $\mathrm{Br}_{2}$ in the source flow was 3-4 depending on $\mathrm{N}_{2}$ flow rates. The amount of $\mathrm{HOBr}$ in the flow was determined by conversion of the $\mathrm{HOBr}$ to $\mathrm{Br}_{2}$ via reactions on humidified $\mathrm{NaBr}$ crystals.

$\mathrm{HOBr}+\mathrm{NaBr} \rightarrow \mathrm{Br}_{2}+\mathrm{Na}^{+}+\mathrm{OH}^{-}$

Assuming a 1:1 yield for this reaction, the relative CIMS sensitivity of $\mathrm{HOBr}$ to $\mathrm{Br}_{2}$ was determined to be $0.5 \pm 0.13$.

$\mathrm{HBr}$ was obtained from a commercial source tube (Kintek Trace Source ${ }^{\mathrm{TM}}$ 57Series Hydrogen bromide), which is a small stainless steel cylinder $(15 \mathrm{~cm} \mathrm{l} \times 4.5 \mathrm{~cm} \mathrm{OD})$ with a Teflon membrane that allows permeation of the HBr. The source was kept at a constant temperature of $30^{\circ} \mathrm{C}$ and $20 \mathrm{sccm}$ of $\mathrm{N}_{2}$ was continuously passed over the source. The output of the $\mathrm{HBr}$ from the source was determined to be

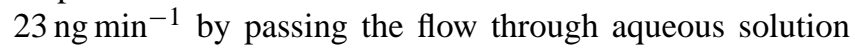
followed by ion chromatographic measurements.

\subsection{BrO and soluble bromide measurements from the DC-8}

The CIMS instrument aboard the NASA DC- 8 aircraft that measured halogens was mechanically nearly identical to the one in the laboratory experiments here but used different ion chemistry. The CIMS utilized $\mathrm{SF}_{6}^{-}$as a reagent to detect halogen and other species (e.g. $\mathrm{BrO}, \mathrm{SO}_{2}$ ) as negative product ions (e.g. $\mathrm{BrO}^{-}, \mathrm{F}_{2} \mathrm{SO}_{2}^{-}$). The configuration and performance of the CIMS instrument are described in Neuman et al. (2010). The CIMS and the MC sampling inlets on the DC8 were $\sim 1 \mathrm{~m}$ and heated to $40^{\circ} \mathrm{C}$. The detection limits of $\mathrm{BrO}$ from the DC-8 ranged from $2-5 \mathrm{pmol} \mathrm{mol}^{-1}$ for a $30 \mathrm{~s} \mathrm{sam}-$ pling period and the measurement uncertainty was $\pm 40 \%$. The DC-8 MC measurements were performed using an instrument described in detail by Scheuer et al. $(2003,2010)$. The soluble bromide detection limit was $1 \mathrm{pmol} \mathrm{mol}^{-1}$ for a $1.5 \mathrm{~min}$ sampling period in the boundary layer and increased with flight altitude to $\sim 6 \mathrm{pmol} \mathrm{mol}^{-1}$ at $12 \mathrm{~km}$. The detection limit for the MC is a function of altitude because a Scroll pump is used to maintain the air flow and mass flow through the MC decreases with inlet pressure. The soluble bromide measurement uncertainty was $\pm\left(15 \%+0.5 \mathrm{pmol} \mathrm{mol}^{-1}\right)$.

\section{3 $\mathrm{HBr}, \mathrm{HOBr}$ and soluble bromide prediction during ARCTAS}

A simple photochemical model was used to predict $\mathrm{HBr}$ and $\mathrm{HOBr}$ levels from CIMS measurements of $\mathrm{BrO}$. The mechanism used in the model includes Reactions (R2)-(R9) as well as the heterogeneous loss of $\mathrm{HBr}$ and $\mathrm{HOBr}$. The model did not include the recycling of $\mathrm{HOBr}$ and $\mathrm{HBr}$ from aqueous phase to gas phase bromine compounds because the model was constrained by $\mathrm{BrO}$ measurements. $\mathrm{HBr}$ and $\mathrm{HOBr}$ were assumed to be in steady state due to their relatively short lifetimes of $\sim 1$ hour and $\sim 8 \mathrm{~min}$, respectively. The lifetime of $\mathrm{HBr}$ is mainly determined by heterogeneous loss on aerosol surfaces (Fan and Jacob et al., 1992; Liao et al., 2011b). Because $\mathrm{NO}_{2}$ mixing ratios $\left(<5 \mathrm{pmol} \mathrm{mol}^{-1}\right)$ were near or below detection limits when significant $\mathrm{BrO}$ was detected $\mathrm{BrO}$ $\left.>3 \mathrm{pmol} \mathrm{mol}^{-1}\right), \mathrm{BrONO}_{2}$ formation was neglected. The photochemical model was constrained by observations of $\mathrm{BrO}$, formaldehyde $\left(\mathrm{CH}_{2} \mathrm{O}\right)$, nitrogen oxide $(\mathrm{NO}), \mathrm{O}_{3}, \mathrm{HO}_{2}$, $J$ values, temperature, pressure, aerosol surface area and aerosol number density on the DC-8. $\mathrm{CH}_{2} \mathrm{O}$ was measured by a difference frequency generation absorption spectrometer (Weibring et al., 2006). $\mathrm{NO}$ and $\mathrm{O}_{3}$ were measured from a 4-channel chemiluminescence instrument (Weinheimer et al., 1998). $J$ values were obtained from NCAR actinic flux spectroradiometers (Shetter and Müller, 1999). Aerosol surface area and number density were measured by an ultra-high sensitivity aerosol spectrometer (UHSAS) (Cai et al., 2008). Constrained $\mathrm{HBr}$ and $\mathrm{HOBr}$ calculations combined with the measured response factors of the MC to these species allowed soluble bromide to be predicted from CIMS observations of $\mathrm{BrO}$. 

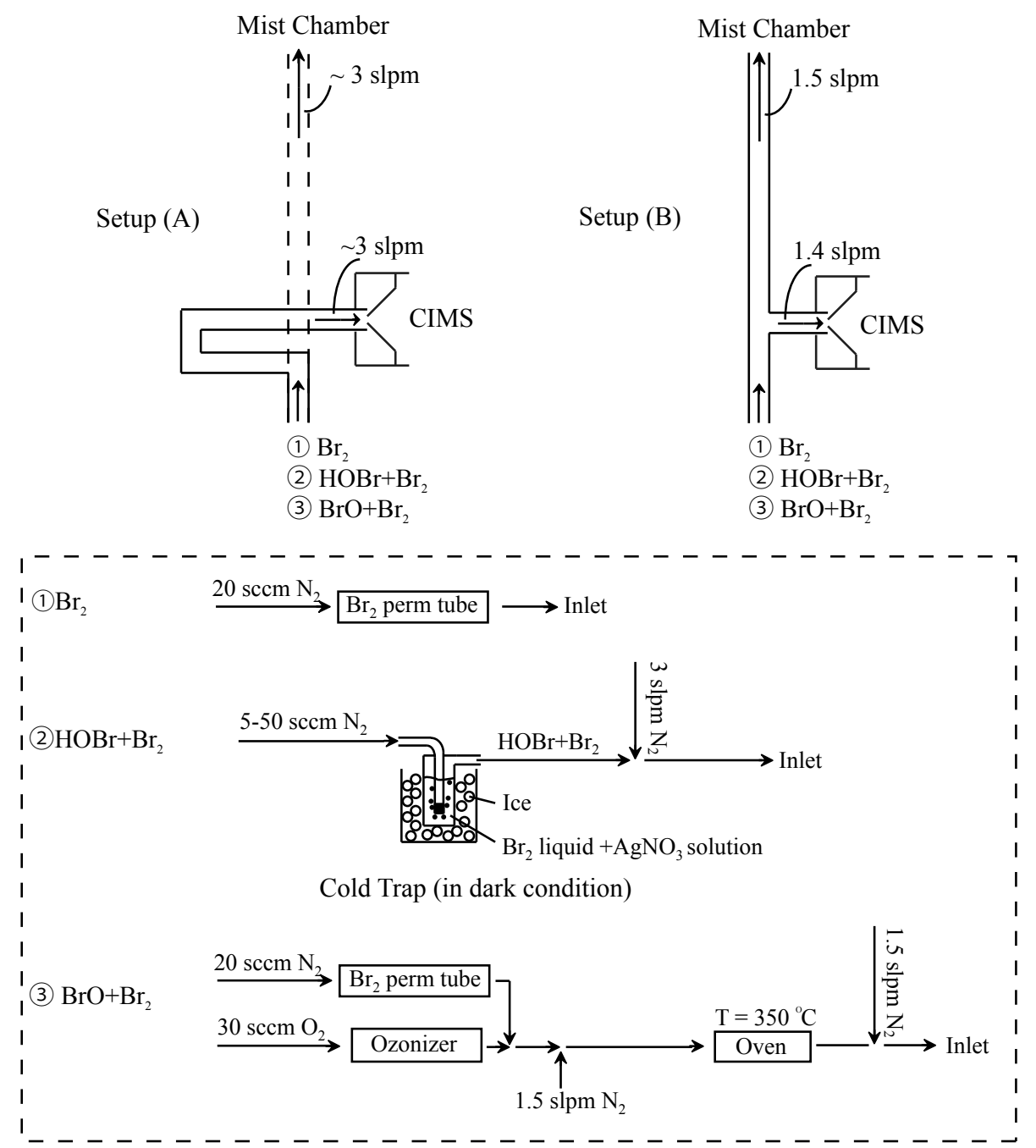

Fig. 1. Inlet configurations and $\mathrm{Br}_{2}, \mathrm{HOBr}$ and $\mathrm{BrO}$ sources for soluble bromide characterization. In setup (A), the solid inlet line presents the sampling inlet connecting to the CIMS and the dashed inlet line denotes the same inlet line connecting to the MC.

\subsection{Satellite-derived tropospheric BrO vertical column density}

The tropospheric $\mathrm{BrO}$ vertical column density (VCD) is derived using the residual method (Theys et al., 2011; Choi et al., 2011). The analysis uses: the slant column density (SCD) of $\mathrm{BrO}$ as provided in the publicly released Ozone Monitoring Instrument (OMI) BrO v3.0 data product (Kurosu and Chance, 2011); air mass factors (ratio of slant to vertical columns) found using a radiative transfer model (Choi et al., 2011); as well as stratospheric column BrO obtained from a model simulation for boreal spring 2008 (Salawitch et al., 2010). A detailed explanation and discussion of the sensitivity of satellite-derived tropospheric column $\mathrm{BrO}$ is given in Choi et al. (2011). Here we provide a brief overview.
OMI is a nadir-viewing ultraviolet and visible (UV/Vis) sensor on the NASA Aura satellite, which is in a sunsynchronous polar orbit with an overpass of $\sim 13: 30$ local time. BrO SCD is retrieved by direct fitting of backscattered $\mathrm{UV}$ radiances to absorption cross-sections of $\mathrm{BrO}$ (the target gas), $\mathrm{NO}_{2}, \mathrm{CH}_{2} \mathrm{O}, \mathrm{SO}_{2}$ and inelastic rotational-Raman scattering (also known as the Ring effect) using a non-linear least-squares approach (Chance, 1998) with a spectral fitting window between 319 and $347.5 \mathrm{~nm}$.

An estimate of stratospheric $\mathrm{BrO}$ VCD is calculated from a model simulation (Salawitch et al., 2010). Distributions of all species other than bromine bearing compounds originate from a run of the Whole Atmosphere Community Climate Model (WACCM) (Garcia et al., 2007) conducted using analyzed winds for April 2008. Vertical distributions of $\mathrm{Br}_{\mathrm{y}}$ (the sum of inorganic bromine species) are specified, using the 
relation between $\mathrm{Br}_{\mathrm{y}}$ and chlorofluorcarbon-12 (CFC-12), as well as profiles of CFC-12 from the NASA Global Modeling and Assimilation Office (GMAO) Goddard Earth Observing System Data Assimilation System Version 5 (GEOS-5) (Rienecker et al., 2007). The contribution of very short lived (VSL) bromocarbons is represented by adding $7 \mathrm{pmol} \mathrm{mol}^{-1}$ to the baseline $\mathrm{Br}_{\mathrm{y}}$ versus CFC-12 relation. The baseline $\mathrm{Br}_{\mathrm{y}}$ relation represents a source of gas injection of the organic bromocarbons that cross the tropopause: bromomethane $\left(\mathrm{CH}_{3} \mathrm{Br}\right)$, halons, and dibromomethane $\left(\mathrm{CH}_{2} \mathrm{Br}_{2}\right)$. Mixing ratios of $\mathrm{BrO}$ at the time of satellite overpass are determined using a photochemical steady state model constrained by radical precursors (e.g., $\mathrm{O}_{3}$, water vapor $\left(\mathrm{H}_{2} \mathrm{O}\right)$, methane $\left(\mathrm{CH}_{4}\right)$, total chlorine species $\left(\mathrm{Cl}_{\mathrm{y}}\right)$, total reactive nitrogen $\left(\mathrm{NO}_{\mathrm{y}}\right)$, $\mathrm{Br}_{\mathrm{y}}$, etc) from WACCM (Choi et al., 2011). The stratospheric $\mathrm{BrO}$ VCD is obtained by integrating the $\mathrm{BrO}$ mixing ratio from the tropopause (WMO definition of thermal tropopause) to $0.01 \mathrm{hPa}$.

AMFs, a ratio of SCD to VCD by definition, are used to convert SCD to VCD (VCD = SCD/AMF). The stratospheric AMF is provided as an OMI total column product. The tropospheric AMF is calculated using the Linearized Discrete Ordinate Radiative Transfer (LIDORT) model (Spurr et al., 2001), which considers the effects of the tropospheric $\mathrm{BrO}$ profile, surface albedo, and viewing geometry (Choi et al., 2011).

The tropospheric BrO VCD is calculated from a tropospheric residual column obtained by subtracting the stratospheric SCD (product of stratospheric VCD and stratospheric AMF) from the total SCD. The tropospheric BrO VCD is then obtained by dividing the residual tropospheric slant column by the tropospheric AMF. Further details are given in Choi et al. (2011). Our approach is similar to that of Theys et al. (2011), except our stratospheric VCD is larger than that used by Theys et al. (2011) and we use an independent radiative transfer model.

\section{Results and discussion}

\subsection{Response of the $\mathrm{MC}$ to $\mathrm{Br}_{2}, \mathrm{HOBr}, \mathrm{BrO}$ and $\mathrm{HBr}$}

$\mathrm{BrO}, \mathrm{HOBr}$, and $\mathrm{HBr}$ are likely the most abundant daytime bromine species when $\mathrm{O}_{3}$ is not completely depleted in the typical Arctic environment $\left(\mathrm{NO}<5 \mathrm{pmol} \mathrm{mol}^{-1}\right.$ ) (Evans et al., 2003). $\mathrm{Br}_{2}$ is the likely dominant nighttime bromine species under this condition. As a result, the detection efficiencies of $\mathrm{BrO}, \mathrm{HOBr}, \mathrm{HBr}$, and $\mathrm{Br}_{2}$ by our $\mathrm{MC}$ were characterized and reported in this study.

\subsection{1 $\mathrm{Br}_{2}$}

The $\mathrm{MC}$ responded to the presence of $\mathrm{Br}_{2}$ in the gas phase as $\mathrm{Br}^{-}$(Table 1). The ratio of detected $\mathrm{Br}^{-}$to $\mathrm{Br}_{2}$ was found to be $0.40 \pm 0.10$ per $\mathrm{Br}$ atom for setup $\mathrm{A}$ and $0.45 \pm 0.10$ per $\mathrm{Br}$ atom for setup $B$ (Table 2). The error bars are estimated from a combination of the estimated potential systematic error in $\mathrm{Br}_{2}$ and $\mathrm{Br}^{-}$measurements and variance of the individual $\mathrm{Br}^{-}$to $\mathrm{Br}_{2}$ ratio measurements. To confirm the nearly complete dissolution of $\mathrm{Br}_{2}$, the $\mathrm{Br}_{2}$ permeation tube output was passed through a trap containing deionized water. The output of the trap was monitored by the CIMS and effectively all $\mathrm{Br}_{2}$ was found to be scrubbed by the solution, consistent with efficient detection of $\mathrm{Br}_{2}$ by the $\mathrm{MC}$. $\mathrm{Br}_{2}$ can be hydrolyzed to form $\mathrm{Br}^{-}$and $\mathrm{HOBr}$ in aqueous solution, with a hydrolysis rate constant, $k_{19}$, of $110 \mathrm{~s}^{-1}$ (at $20^{\circ} \mathrm{C}$ ) (Eigen and Kustin, 1962). This suggests that each $\mathrm{Br}_{2}$ molecule produces one bromide ion which is detected with near $100 \%$ efficiency by the $\mathrm{MC}$. The $\mathrm{HOBr}$ produced in aqueous solution in the MC does not appear to convert to bromide on the time scale of the measurement $(5 \mathrm{~min}$ ). Thus an efficiency of $\sim 0.5$ (on a per molecule basis) for detecting the bromine atoms in $\mathrm{Br}_{2}$ as bromide is consistent with its known solution chemistry.

\subsubsection{HOBr}

The MC was found to consistently respond to the presence of $\mathrm{HOBr}$ as bromide (Table 1). This is likely due to conversion of $\mathrm{HOBr}$ on the sampling surfaces to $\mathrm{Br}_{2}$, which is detected by the $\mathrm{MC}$ as $\mathrm{Br}^{-}$. The ratio of $\mathrm{HOBr}$ to $\mathrm{Br}^{-}$detected is $0.41+0.15 /-0.17$ for setup $A$ and is $1.06+0.30 /-0.35$ for setup B (Table 2). The error bars are calculated from a combination of the estimated potential systematic error in $\mathrm{HOBr}$ and $\mathrm{Br}^{-}$measurements and the variance of the individual $\mathrm{Br}^{-}$to $\mathrm{HOBr}$ ratio measurements. The assymetrical error bars are due to the presence of $\mathrm{HBr}$ (undetected by CIMS) of up to $5 \%$ of the $\mathrm{HOBr}$ concentration. The results for $\mathrm{Br}_{2}$ indicate that $\mathrm{HOBr}$ in aqueous solution in the $\mathrm{MC}$ is not detected as bromide. However, Neuman et al. (2010) has demonstrated that gas phase $\mathrm{HOBr}$ is readily converted to $\mathrm{Br}_{2}$ on even nominally clean surfaces due to the possible presence of $\mathrm{HBr}$ from $\mathrm{HOBr}+\mathrm{Br}_{2}$ mixture. The greater detection efficiency for $\mathrm{HOBr}$ in the $\mathrm{MC}$ for the longer inlet setup $\mathrm{B}$ is also consistent with conversion of $\mathrm{HOBr}$ to $\mathrm{Br}_{2}$, with some of the bromine coming from the inlet surface. The resulting $\mathrm{Br}_{2}$ will hydrolyze and be detected in the $\mathrm{MC}$ as described above. Consequently, $\mathrm{HOBr}$ will be detected efficiently as bromide by the MC via conversion on the inlet and other surfaces to $\mathrm{Br}_{2}$.

$\mathrm{HOBr} \rightarrow \mathrm{Br}_{2} \stackrel{\mathrm{k} 19}{\longrightarrow} \mathrm{Br}^{-}$

\subsubsection{BrO}

$\mathrm{BrO}$ was also detected as soluble bromide by the MC. The ratio of $\mathrm{BrO}$ to $\mathrm{Br}^{-}$was found to be $0.4 \pm 0.1$ (Table 2). $\mathrm{BrO}$ was only measured in the MC in setup $\mathrm{B}$ because there is no evidence for the conversion of $\mathrm{BrO}$ on inlet surfaces in laboratory tests, which is further supported by the excellent agreement between CIMS and LP-DOAS measurements at Barrow, AK (Liao et al., 2011a). As this result was somewhat surprising, it was confirmed by repeatedly turning on and off 
Table 1. The response of the $\mathrm{MC}$ to $\mathrm{Br}_{2}$ and $\mathrm{HOBr}$ from setup $\mathrm{A}$ and $\mathrm{B}$.

\begin{tabular}{|c|c|c|c|c|}
\hline Setup A & $\begin{array}{l}\text { Soluble bromide } \\
\mathrm{Br}^{-}\left(\mathrm{nmol} \mathrm{mol}^{-1}\right)\end{array}$ & $\begin{array}{l}\mathrm{Br}_{2} \\
\left(\mathrm{nmol} \mathrm{mol}^{-1}\right)\end{array}$ & $\begin{array}{l}\mathrm{HOBr} \\
\left(\mathrm{nmol} \mathrm{mol}^{-1}\right)\end{array}$ & $\begin{array}{l}\text { Ratio }=\mathrm{Br}^{-} / \\
\left(\mathrm{Br}_{2} \times 2+\mathrm{HOBr}\right)\end{array}$ \\
\hline $\begin{array}{l}\mathrm{HOBr}+\mathrm{Br}_{2} \text { mixture } \\
\left(\mathrm{N}_{2} \text { flow }=25 \mathrm{sccm}\right)\end{array}$ & 5.6 & 1.7 & 9.8 & 0.42 \\
\hline $\mathrm{Br}_{2}$ permeation tube & 2.5 & 3.3 & 0.0 & 0.38 \\
\hline $\begin{array}{l}\mathrm{HOBr}+\mathrm{Br}_{2} \text { mixture } \\
\left(\mathrm{N}_{2} \text { flow }=25 \mathrm{sccm}\right)\end{array}$ & 5.1 & 2.2 & 7.9 & 0.42 \\
\hline $\begin{array}{l}\mathrm{HOBr}+\mathrm{Br}_{2} \text { mixture } \\
\left(\mathrm{N}_{2} \text { flow }=10 \mathrm{sccm}\right)\end{array}$ & 1.8 & 0.9 & 3.3 & 0.36 \\
\hline $\mathrm{Br}_{2}$ permeation tube & 2.7 & 3.3 & 0.0 & 0.41 \\
\hline $\begin{array}{l}\mathrm{HOBr}+\mathrm{Br}_{2} \text { mixture } \\
\left(\mathrm{N}_{2} \text { flow }=10 \mathrm{sccm}\right)\end{array}$ & 1.9 & 0.8 & 2.8 & 0.44 \\
\hline Setup B & $\begin{array}{l}\text { Soluble bromide } \\
\mathrm{Br}^{-}\left(\mathrm{nmol} \mathrm{mol}^{-1}\right)\end{array}$ & $\begin{array}{l}\mathrm{Br}_{2} \\
\left(\mathrm{nmol} \mathrm{mol}^{-1}\right)\end{array}$ & $\begin{array}{l}\mathrm{HOBr} \\
\left(\mathrm{nmol} \mathrm{mol}^{-1}\right)\end{array}$ & $\begin{array}{l}\text { Ratio }=\mathrm{Br}^{-} / \\
\left(\mathrm{Br}_{2} \times 2+\mathrm{HOBr} \times 2\right)\end{array}$ \\
\hline $\mathrm{Br}_{2}$ permeation tube & 3.4 & 3.8 & 0 & 0.45 \\
\hline $\begin{array}{l}\mathrm{HOBr}+\mathrm{Br}_{2} \text { mixture } \\
\left(\mathrm{N}_{2} \text { flow }=30 \mathrm{sccm}\right)\end{array}$ & 10.5 & 2.4 & 8.8 & 0.47 \\
\hline $\begin{array}{l}\mathrm{HOBr}+\mathrm{Br}_{2} \text { mixture } \\
\left(\mathrm{N}_{2} \text { flow }=30 \mathrm{sccm}\right)\end{array}$ & 12.4 & 2.7 & 9.1 & 0.53 \\
\hline $\begin{array}{l}\mathrm{HOBr}+\mathrm{Br}_{2} \text { mixture } \\
\left(\mathrm{N}_{2} \text { flow }=20 \mathrm{sccm}\right)\end{array}$ & 9.6 & 1.7 & 6.4 & 0.59 \\
\hline
\end{tabular}

Table 2. The ratio of detected $\mathrm{Br}^{-}$to $\mathrm{Br}_{2}, \mathrm{HOBr}$ and $\mathrm{BrO}$. The errors are estimated from the uncertainties in $\mathrm{Br}_{2}, \mathrm{HOBr}, \mathrm{BrO}$ and $\mathrm{Br}^{-}$measurements and the variance (one standard deviation) of the individual ratio measurements.

\begin{tabular}{llll}
\hline & $\mathrm{Br}^{-} /\left(\mathrm{Br}_{2} \times 2\right)$ & $\mathrm{Br}^{-} / \mathrm{HOBr}$ & $\mathrm{Br}^{-} / \mathrm{BrO}$ \\
\hline Setup A & $0.40 \pm 0.10$ & $0.41+0.15 /-0.17$ & - \\
Setup B & $0.45 \pm 0.10$ & $1.06+0.3 /-0.35$ & $0.4 \pm 0.1$ \\
\hline
\end{tabular}

"-_" reflects that no BrO tests were done using setup A in this experiment.

the $\mathrm{BrO}$ from the $\mathrm{Br}_{2} / \mathrm{O}_{3}$ source by modulating the ozone levels. In addition, tests with the CIMS confirmed that $\mathrm{BrO}$ in a gas stream is removed by deionized water. At this time the mechanism for the conversion of $\sim 40 \%$ of $\mathrm{BrO}$ to $\mathrm{Br}_{(\mathrm{aq})}^{-}$ in this experiment is not determined.

\subsubsection{HBr}

The sensitivity ratio of $\mathrm{HBr}$ to $\mathrm{Br}_{2}$ measured by CIMS using reagent ion $\mathrm{I}^{-}$was less than 1:100, which implies that the CIMS instrument using reagent ion $\mathrm{I}^{-}$has a very low sensitivity for detecting $\mathrm{HBr}$. The CIMS was not used to quantify $\mathrm{HBr}$ and the $\mathrm{HBr}$ permeation tube output was determined to be $23 \mathrm{ng} \mathrm{min}^{-1}$ by ion chromatography. The MC detected $\mathrm{HBr}$ with $0.95 \pm 0.1$ efficiency. This is consistent with detection of effectively $100 \%$ of $\mathrm{HBr}$ as soluble bromide by the MC.

\subsubsection{Implications for soluble bromide measurements}

The results above indicate that the MC measurements of soluble bromide during ARCTAS (and other missions such as Tropospheric Ozone Production around the Spring Equinox (TOPSE)) (Ridley et al., 2003) are due to a multitude of compounds. As conversion of $\mathrm{HOBr}$ to $\mathrm{Br}_{2}$ on the walls of the MC or sampling line was very likely, soluble bromide $\left(\left[\mathrm{Br}^{-}\right]\right)$can be estimated by the following equation based on our experiment setup.

$\left[\mathrm{Br}^{-}\right]=0.9\left[\mathrm{Br}_{2}\right]+1.0[\mathrm{HOBr}]+0.4[\mathrm{BrO}]+0.95[\mathrm{HBr}]$.

This indicates that a well characterized MC can be used to derive the mixing ratios of some reactive bromine compounds and examine the areas of active bromine chemistry where $\mathrm{BrO}$ and $\mathrm{HOBr}$ are enhanced.

\subsection{Case study of BrO and soluble bromide measurements}

On research flight 17 April 2008 of ARCTAS the highest bromine levels for the mission were observed. During this flight the NASA DC-8 frequently sampled ozone depleted air masses, with significant levels of bromine in the Arctic boundary layer. The aircraft track for this flight from Fairbanks, AK to the North Pole is displayed in the top panel of Fig. 2. The flight track is color coded by altitude. The aircraft sampled boundary layer air five times during this flight. $\mathrm{O}_{3}$ depletions were clearly observed when the boundary layer 


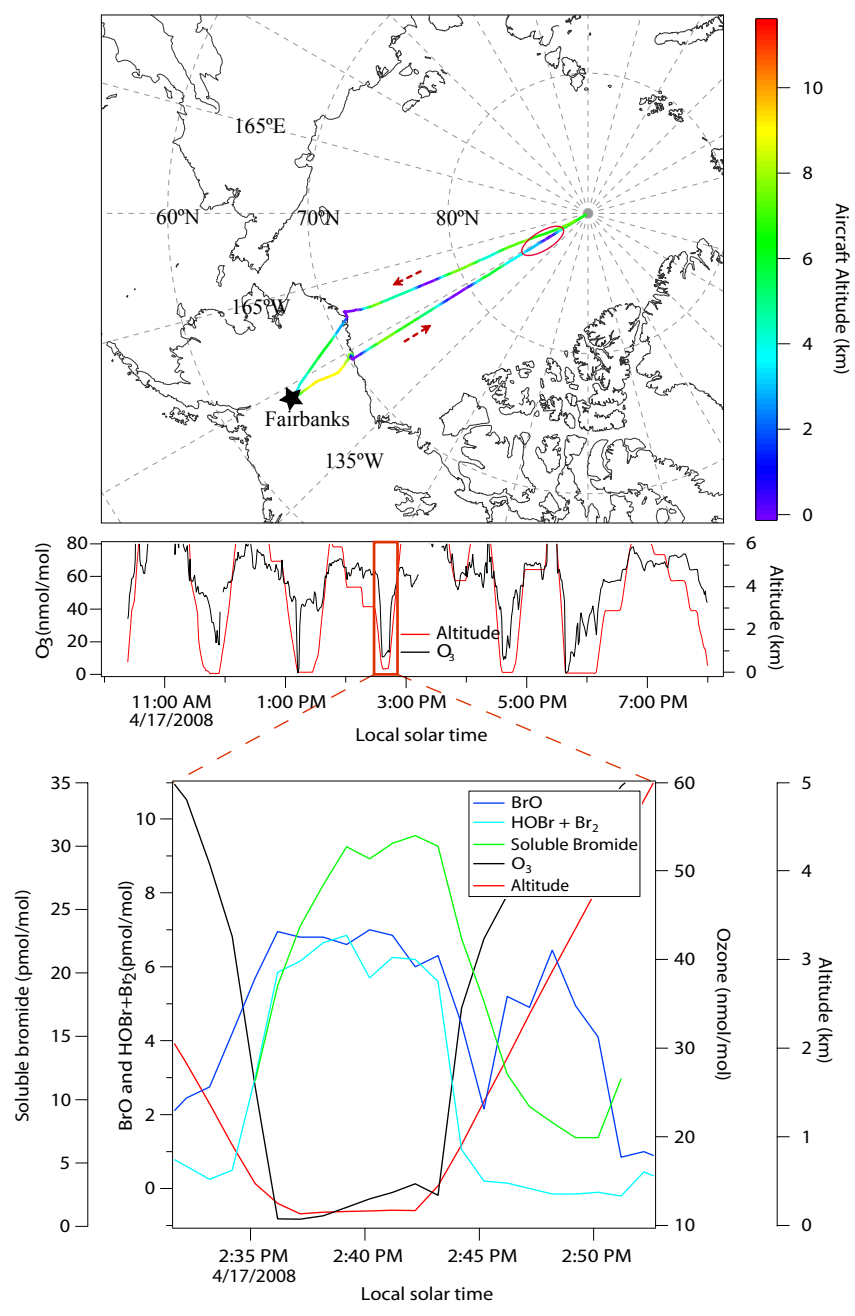

Fig. 2. Top panel: The flight track of the NASA DC-8 on 17 April 2008 color-coded with aircraft altitudes. The black star denotes the beginning of the flight and the dashed arrows represents the direction of the flight. The red circle shows the location on the flight track that corresponds to the bottom panel. Middle panel: Time series of observations of ozone and altitude. Bottom panel: Observations of soluble bromide, $\mathrm{BrO}$, lower limit of $\mathrm{Br}_{2}+\mathrm{HOBr}, \mathrm{O}_{3}$ and altitude for the flight leg with the highest levels of bromine.

was sampled (middle panel of Fig. 2). Further description of this flight is given by Choi et al. (2011).

The observations of $\mathrm{BrO}, \mathrm{Br}_{2}+\mathrm{HOBr}$, soluble bromide, $\mathrm{O}_{3}$, and altitude on one flight leg in the boundary layer, where maximum bromine was detected, are shown in the bottom panel of Fig. 2. The corresponding region on the map is denoted with the red circle in the top panel of Fig. 2. Ozone depletion and elevated bromine (soluble bromide, $\mathrm{Br}_{2}+\mathrm{HOBr}$ and $\mathrm{BrO}$ ) were clearly measured when the aircraft flew down to the boundary layer (altitude $<200 \mathrm{~m}$ ). The maximum soluble bromide detected during this flight was $\sim 31 \mathrm{pmol} \mathrm{mol}^{-1}$, when ozone was depleted to $\sim 10 \mathrm{nmol} \mathrm{mol}^{-1}$, and up to $\sim 7 \mathrm{pmol} \mathrm{mol}^{-1} \mathrm{BrO}$ and $\mathrm{HOBr}+\mathrm{Br}_{2}$ were detected by

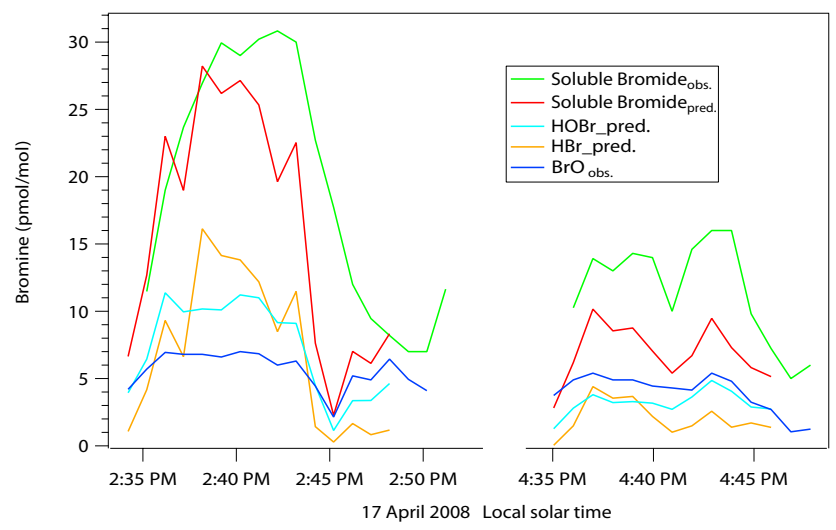

Fig. 3. Example of observed $\mathrm{BrO}$ and soluble bromide, and predicted $\mathrm{HOBr}, \mathrm{HBr}$ and soluble bromide for two marine boundary layer flight legs when the highest levels of $\mathrm{BrO}$ and soluble bromide were observed.

CIMS. HOBr was not monitored by CIMS during ARCTAS as the reagent ion, $\mathrm{SF}_{6}^{-}$, does not selectively react with $\mathrm{HOBr}$ (Huey et al., 1995). Due to the conversion of $\mathrm{HOBr}$ on the Teflon inlet (Neuman et al., 2010), the CIMS $\mathrm{Br}_{2}$ signal represents the lower limit to the sum $\mathrm{Br}_{2}+\mathrm{HOBr}$. As the mixing ratio of rapidly photolyzed $\mathrm{Br}_{2}$ in the daytime is likely to be very low $\left(<=\sim 1 \mathrm{pmol} \mathrm{mol}^{-1}\right.$ ) (Fan and Jacob, 1992; Liao et al., 2011b), the $\mathrm{Br}_{2}$ signal is highly likely to correspond to $\mathrm{HOBr}$

To assess whether the mixing ratios of $\mathrm{BrO}$ reported by the CIMS instrument are consistent with the soluble bromide observations from the $\mathrm{MC}$, we first calculated the abundances of $\mathrm{HBr}$ and $\mathrm{HOBr}$ using a photochemical model (described in Sect. 2.3) constrained by the measurements of $\mathrm{BrO}$ and other species. Soluble bromide was then calculated based on measured detection efficiency for $\mathrm{BrO}, \mathrm{HOBr}$, and $\mathrm{HBr}$ (see Eq. 1). An example of observed $\mathrm{BrO}$ and soluble bromide and modeled $\mathrm{HOBr}, \mathrm{HBr}$ and soluble bromide on two flight legs, both with $\mathrm{BrO}$ above detection limit $\left(>2 \mathrm{pmol} \mathrm{mol}^{-1}\right)$, is shown in Fig. 3. The correlation plot of modeled and observed soluble bromide during the 17 April 2008 flight when $\mathrm{BrO}$ was above detection limit under unpolluted conditions $\left(\mathrm{NO}<10 \mathrm{pmol} \mathrm{mol}^{-1}\right)$ is shown in the left panel of Fig. 4. Except for pollution plumes where high levels of NO $\left(>100 \mathrm{pmol} \mathrm{mol}^{-1}\right)$ were observed, the mixing ratios of $\mathrm{NO}$ were less than $10 \mathrm{pmol} \mathrm{mol}^{-1}$ and $\mathrm{NO}_{2}$ was near the detection limit of $\sim 5 \mathrm{pmol} \mathrm{mol}^{-1}$. Considering the measurement uncertainties in $\mathrm{BrO}(\sim 40 \%)$, soluble bromide, $J$ values, reaction rates, mass accommodation coefficients, and aerosol surface areas, the agreement $\left(R^{2}=0.76 ;\right.$ slope $=0.95 ;$ intercept $\left.=-3.4 \mathrm{pmol} \mathrm{mol}^{-1}\right)$ between measured and modeled soluble bromide indicates that reported soluble bromide mixing ratios by the $\mathrm{MC}$ are consistent with the $\mathrm{BrO}$ measurements from the CIMS instrument as well as our current understanding of inorganic bromine photochemistry. It is also interesting to note that the modeled 

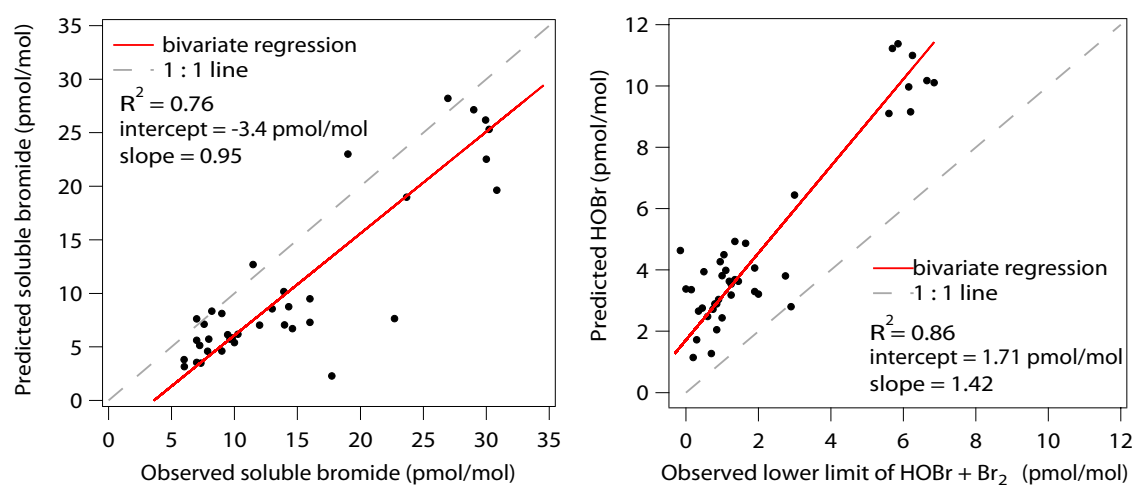

Fig. 4. Left panel: correlation plot of predicted and observed soluble bromide in the boundary layer when BrO was above the detection limit $\left(>2 \mathrm{pmol} \mathrm{mol}^{-1}\right)$ under unpolluted conditions $\left(\mathrm{NO}<10 \mathrm{pmol} \mathrm{mol}^{-1}\right)$. The correlation coefficient for this plot is 0.76 . An equally weighted bivariate regression yields a slope of 0.95 and an intercept of $-3.4 \mathrm{pmol} \mathrm{mol}^{-1}$. Right panel: correlation plot of predicted $\mathrm{HOBr}$ and observed lower limit of $\mathrm{HOBr}+\mathrm{Br}_{2}$ when $\mathrm{BrO}$ was above detection limit $\left(>2 \mathrm{pmol} \mathrm{mol}^{-1}\right)$ under unpolluted condition $\left(\mathrm{NO}<10 \mathrm{pmol} \mathrm{mol}^{-1}\right)$. The $\mathrm{x}$-axis of the right panel is the lower limit of $\mathrm{HOBr}+\mathrm{Br}_{2}$ as only the fraction of $\mathrm{HOBr}$ converted to $\mathrm{Br}_{2}$ in the inlet is observed by the CIMS. The correlation coefficient $\left(R^{2}\right)$ for this plot is 0.86 . An equally weighted bivariate regression yields a slope of 1.42 and an intercept of $1.71 \mathrm{pmol} \mathrm{mol}^{-1}$.

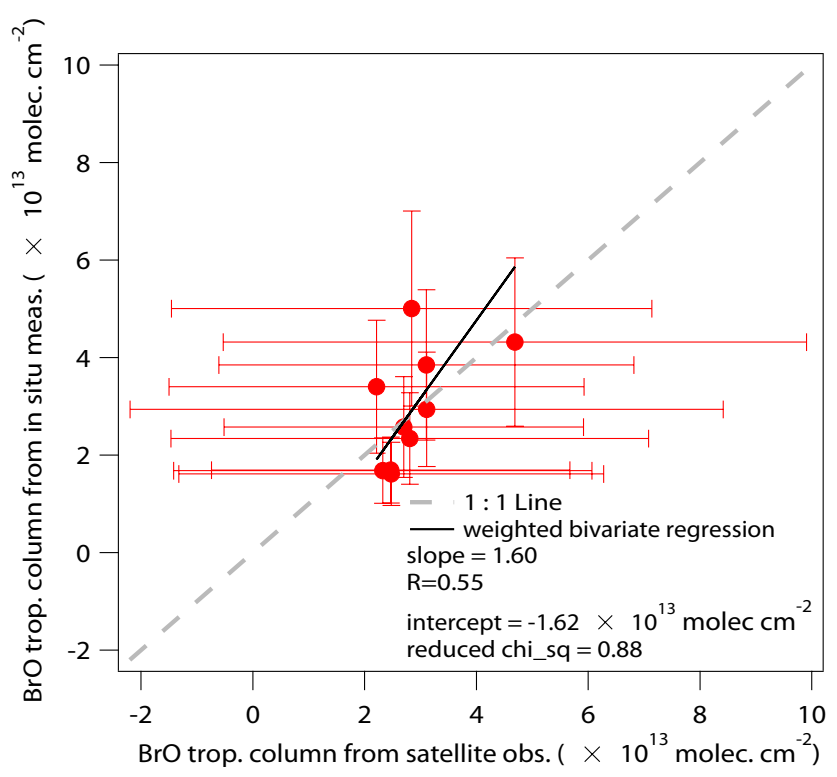

Fig. 5. Scatter plot of calculated $\mathrm{BrO}_{\mathrm{TROP}}^{\mathrm{VCD}}$ from in situ measurements along the flight track of flight on 17 April versus $\mathrm{BrO}_{\mathrm{TROP}}^{\mathrm{VCD}}$ from OMI satellite observations. The satellite columns are for pixels closest in space and time to the aircraft profiles that resulted in the tropospheric columns (see text). Slope and intercept from weighted bivariate regression and the reduced chi-square are given.

$\mathrm{HOBr}$ was well correlated with the measured $\mathrm{HOBr}+\mathrm{Br}_{2}$ $\left(R^{2}=0.86\right.$, slope $=1.42$, intercept $\left.=1.71 \mathrm{pmol} \mathrm{mol}^{-1}\right)($ Fig. 4 right panel), consistent with the assumption of efficient conversion of $\mathrm{HOBr}$ on the inlet walls.

\subsection{Comparison of $\mathrm{BrO}$ satellite observations with in situ BrO measurements}

The region of the Arctic sampled by the DC- 8 on 17 April 2008 provides ideal conditions for comparison of satellite and aircraft determinations of tropospheric BrO. The sky was clear, the surface was bright, and the viewing geometry was amenable for high sensitivity to tropospheric $\mathrm{BrO}$ by satellite sensors (Choi et al., 2011). Here, the comparisons are made in terms of tropospheric $\mathrm{BrO}$ vertical column density $\left(\mathrm{BrO}_{\mathrm{TROP}}^{\mathrm{VCD}}\right)$. The OMI retrieval team reports total vertical column density of $\mathrm{BrO}$. These data are post-processed using a radiative transfer model and an estimate of the stratospheric burden to yield $\mathrm{BrO}_{\mathrm{TROP}}^{\mathrm{VCD}}$ (Theys et al., 2011; Choi et al., 2011).

Estimated $\mathrm{BrO}_{\mathrm{TROP}}^{\mathrm{VCD}}$ from DC-8 in situ measurements of $\mathrm{BrO}$ on the 17 April 2008 flight are compared to $\mathrm{BrO}_{\mathrm{TROP}}^{\mathrm{VCD}}$ retrieved from OMI pixels closest in space and time to the DC-8 flight track (Choi et al., 2011) in Fig. 5. BrO $\mathrm{TROP}$ from airborne in situ $\mathrm{BrO}$ was calculated by integrating the profile of $\mathrm{BrO}$ from the surface to $7.5 \mathrm{~km}$ altitude. The lowest altitude sampled by the aircraft during individual profiles ranged from 100 to $500 \mathrm{~m}$. When finding $\mathrm{BrO}_{\mathrm{TROP}}^{\mathrm{VCD}}$, we assumed the $\mathrm{BrO}$ mixing ratio between the surface and the lowest sampled altitude was the median of values between $500 \mathrm{~m}$ and the lowest sampled altitude. The median DC- 8 profile of $\mathrm{BrO}$, for all of ARCTAS, was used for altitudes between the highest sampled by the DC- 8 for a particular profile and $7.5 \mathrm{~km}$. Since $\mathrm{BrO}$ was below the detection limit of CIMS above $7.5 \mathrm{~km}$ altitude, we assumed $\mathrm{BrO}$ was zero between $7.5 \mathrm{~km}$ and the tropopause. The error bars in Fig. 5 represent the uncertainties in satellite $\mathrm{BrO}_{\mathrm{TROP}}^{\mathrm{VCD}}$ (horizontal) and in situ $\mathrm{BrO}_{\text {TROP }}^{\mathrm{VCD}}$ (vertical), respectively. These uncertainties are described in detail by Choi et al. (2011). 
An orthogonal least square regression was used to analyze the agreement between satellite and in situ $\mathrm{BrO}_{\mathrm{TROP}}^{\mathrm{VCD}}$. Reduced chi-square is calculated by the minimum of the sum of the squared orthogonal distance between the measurements and the 1: 1 line.

$\chi^{2}=\frac{1}{n-2} \sum_{i} \frac{\left(X_{i}-x_{i}\right)^{2}}{\sigma_{x i}^{2}}+\frac{\left(Y_{i}-y_{i}\right)^{2}}{\sigma_{\mathrm{yi}}^{2}}$

A value for reduced chi-square of 0.88 means the determinations of $\mathrm{BrO}_{\mathrm{TROP}}^{\mathrm{VCD}}$ from in situ sampling and satellite retrieval agree, to within the measurement uncertainty. The satellite retrieval of tropospheric $\mathrm{BrO}$ using updated methods (Choi et al., 2011) captures the levels of BrO found by the CIMS instrument. This result, combined with the consistency between CIMS BrO and MC soluble bromide, represents an important advance in the quantitative understanding of tropospheric bromine chemistry.

\section{Summary}

Characterization of the MC response to gas phase bromine species enables better use of soluble bromide data from previous and future field missions focusing on polar halogen chemistry. In this study, the response of the $\mathrm{MC}$ to $\mathrm{Br}_{2}$, $\mathrm{HOBr}, \mathrm{BrO}$ and $\mathrm{HBr}$ as soluble bromide $\left(\mathrm{Br}^{-}\right)$was measured. The MC was found to detect bromine compounds $\mathrm{Br}_{2}, \mathrm{HOBr}, \mathrm{BrO}$, and $\mathrm{HBr}$ as soluble bromide with an efficiency per molecule of $0.9 \pm 0.1,1.06+0.30 /-0.35,0.4 \pm 0.1$, and $0.95 \pm 0.1$, respectively. As $\mathrm{HOBr}$ converts to $\mathrm{Br}_{2}$ on surfaces, the detection efficiency of $\mathrm{HOBr}$ as soluble bromide by $\mathrm{MC}$ can vary with inlet length. These measured response factors (except that of $\mathrm{Br}_{2}$ ) were used to model soluble bromide from CIMS measurements of $\mathrm{BrO}$ obtained on the 17 April 2008 flight of the NASA DC-8 during ARCTAS. The agreement $\left(R^{2}=0.76 ;\right.$ slope $=0.95 ;$ intercept $\left.=-3.4 \mathrm{pmol} \mathrm{mol}^{-1}\right)$ between measured and observed soluble bromide, when $\mathrm{BrO}$ was above the detection limit $\left(>2 \mathrm{pmol} \mathrm{mol}^{-1}\right)$ under unpolluted conditions $\left(\mathrm{NO}<10 \mathrm{pmol} \mathrm{mol}^{-1}\right)$, indicates that airborne in situ $\mathrm{BrO}$ measurements by CIMS were consistent with the observed soluble bromide. BrO column densities calculated from CIMS measurements were also consistent with the tropospheric $\mathrm{BrO}$ columns derived from OMI satellite data, using a stratospheric burden that includes a significant contribution from VSL bromocarbons. This study also indicates that a fully characterized MC and inlet can be used to derive the mixing ratios of active bromine species with the bromine chemical mechanism.

Acknowledgements. This work was funded by the NASA Tropospheric Program - Contract NNX08AR67G, NASA Aura Science, ACMAP, and ARCTAS.

Edited by: J. W. Bottenheim

\section{References}

Anlauf, K. G., Mickle, R. E., and Trivett, N. B. A.: Measurement of ozone during polar sunrise experiment, J. Geophys. Res.-Atmos., 99, 25345-25353, 1994.

Barrie, L. A., Bottenheim, J. W., Schnell, R. C., Crutzen, P. J., and Rasmussen, R. A.: Ozone destruction and photochemicalreactions at polar sunrise in the lower Arctic atmosphere, Nature, 334, 138-141, 1988.

Bottenheim, J. W., Fuentes, J. D., Tarasick, D. W., and Anlauf, K. G.: Ozone in the Arctic lower troposphere during winter and spring 2000 (ALERT2000), Atmos. Environ., 36, 2535-2544, 2002.

Bottenheim, J. W., Netcheva, S., Morin, S., and Nghiem, S. V.: Ozone in the boundary layer air over the Arctic Ocean: measurements during the TARA transpolar drift 2006-2008, Atmos. Chem. Phys., 9, 4545-4557, doi:10.5194/acp-9-4545-2009, 2009.

Brock, C. A., Cozic, J., Bahreini, R., Froyd, K. D., Middlebrook, A. M., McComiskey, A., Brioude, J., Cooper, O. R., Stohl, A., Aikin, K. C., de Gouw, J. A., Fahey, D. W., Ferrare, R. A., Gao, R. S., Gore, W., Holloway, J. S., Hubler, G., Jefferson, A., Lack, D. A., Lance, S., Moore, R. H., Murphy, D. M., Nenes, A., Novelli, P. C., Nowak, J. B., Ogren, J. A., Peischl, J., Pierce, R. B., Pilewskie, P., Quinn, P. K., Ryerson, T. B., Schmidt, K. S., Schwarz, J. P., Sodemann, H., Spackman, J. R., Stark, H., Thomson, D. S., Thornberry, T., Veres, P., Watts, L. A., Warneke, C., and Wollny, A. G.: Characteristics, sources, and transport of aerosols measured in spring 2008 during the aerosol, radiation, and cloud processes affecting Arctic Climate (ARCPAC) Project, Atmos. Chem. Phys., 11, 2423-2453, doi:10.5194/acp-11-24232011, 2011.

Cai, Y., Montague, D. C., Mooiweer-Bryan, W., and Deshler, T.: Performance characteristics of the ultra high sensitivity aerosol spectrometer for particles between 55 and $800 \mathrm{~nm}$ : Laboratory and field studies, J. Aerosol Sci., 39, 759-769, doi:10.1016/j.jaerosci.2008.04.007, 2008.

Chance, K.: Analysis of BrO measurements from the Global Ozone Monitoring Experiment, Geophys. Res. Lett., 25, 3335-3338, 1998.

Choi, S., Wang, Y., Salawitch, R. J., Canty, T., Joiner, J., Zeng, T., Kurosu, T. P., Chance, K., Richter, A., Huey, L. G., Liao, J., Neuman, J. A., Nowak, J. B., Dibb, J. E., Weinheimer, A. J., Diskin, G., Ryerson, T. B., da Silva, A., Curry, J., Kinnison, D., Tilmes, S., and Levelt, P. F.: Analysis of satellite-derived Arctic tropospheric BrO columns in conjunction with aircraft measurements during ARCTAS and ARCPAC, Atmos. Chem. Phys. Discuss., 11, 26173-26243, doi:10.5194/acpd-11-26173-2011, 2011.

Dibb, J. E., Talbot, R. W., and Bergin, M. H.: Soluble acidic species in air and snow at Summit, Greenland, Geophys. Res. Lett., 21, 1627-1630, 1994.

Dibb, J. E., Talbot, R. W., Munger, J. W., Jacob, D. J., and Fan, S. M.: Air-snow exchange of $\mathrm{HNO}_{3}$ and $\mathrm{NO}_{\mathrm{y}}$ at Summit, Greenland, J. Geophys. Res.-Atmos., 103, 3475-3486, 1998.

Dibb, J. E., Ziemba, L. D., Luxford, J., and Beckman, P.: Bromide and other ions in the snow, firn air, and atmospheric boundary layer at Summit during GSHOX, Atmos. Chem. Phys., 10, 99319942, doi:10.5194/acp-10-9931-2010, 2010.

Eigen, M. and Kustin, K.: Kinetics of halogen hydrolysis, J. Am. Chem. Soc., 84, 1355-1361, 1962. 
Evans, M. J., Jacob, D. J., Atlas, E., Cantrell, C. A., Eisele, F., Flocke, F., Fried, A., Mauldin, R. L., Ridley, B. A., Wert, B., Talbot, R., Blake, D., Heikes, B., Snow, J., Walega, J., Weinheimer, A. J., and Dibb, J.: Coupled evolution of $\mathrm{BrO}_{\mathrm{x}}-\mathrm{ClO}_{\mathrm{x}}-\mathrm{HO}_{\mathrm{x}}-\mathrm{NO}_{\mathrm{x}}$ chemistry during bromine-catalyzed ozone depletion events in the arctic boundary layer, J. Geophys. Res.-Atmos., 108, 8368, doi:10.1029/2002jd002732, 2003.

Fan, S. M. and Jacob, D. J.: Surface ozone depletion in Arctic spring sustained by bromine reactions on aerosols, Nature, 359, 522524, 1992.

Garcia, R. R., Marsh, D. R., Kinnison, D. E., Boville, B. A., and Sassi, F.: Simulations of secular trends in the middle atmosphere, 1950-2003, J. Geophys. Res., 112, D09301, doi:10.1029/2006JD007485, 2007.

Hausmann, M. and Platt, U.: Spectroscopic measurement of bromine oxide and ozone in the high Arctic during polar sunrise experiment 1992, J. Geophys. Res.-Atmos., 99, 25399-25413, 1994.

Holmes, C. D., Jacob, D. J., Corbitt, E. S., Mao, J., Yang, X., Talbot, R., and Slemr, F.: Global atmospheric model for mercury including oxidation by bromine atoms, Atmos. Chem. Phys., 10, 12037-12057, doi:10.5194/acp-10-12037-2010, 2010.

Huey, L. G., Hanson, D. R., and Howard, C. J.: Reactions of $\mathrm{SF}_{6}^{-}$ and $\mathrm{I}^{-}$with atmospheric trace gases, J. Phys. Chem., 99, 50015008, doi:10.1021/j100014a021, 1995.

Huey, L. G.: Measurement of trace atmospheric species by chemical ionization mass spectrometry: Speciation of reactive nitrogen and future directions, Mass Spectrom. Rev., 26, 166-184, doi:10.1002/mas.20118, 2007.

Jacob, D. J., Crawford, J. H., Maring, H., Clarke, A. D., Dibb, J. E., Emmons, L. K., Ferrare, R. A., Hostetler, C. A., Russell, P. B., Singh, H. B., Thompson, A. M., Shaw, G. E., McCauley, E., Pederson, J. R., and Fisher, J. A.: The Arctic Research of the Composition of the Troposphere from Aircraft and Satellites (ARCTAS) mission: design, execution, and first results, Atmos. Chem. Phys., 10, 5191-5212, doi:10.5194/acp-10-5191-2010, 2010.

Jin, R. H. and Chu, L. T.: Uptake of $\mathrm{NH}_{3}$ and $\mathrm{NH}_{3}+\mathrm{HOBr}$ reaction on ice surfaces at $190 \mathrm{~K}$, J. Phys. Chem. A, 111, 7833-7840, doi:10.1021/jp073233m, 2007.

Jobson, B. T., Niki, H., Yokouchi, Y., Bottenheim, J., Hopper, F., and Leaitch, R.: Measurements of $\mathrm{C}_{2}-\mathrm{C}_{6}$ hydrocarbons during the polar sunrise 1992 experiment - Evidence for $\mathrm{Cl}$ atom and Br atom chemistry, J. Geophys. Res.-Atmos., 99, 25355-25368, 1994.

Jones, A. E., Anderson, P. S., Begoin, M., Brough, N., Hutterli, M. A., Marshall, G. J., Richter, A., Roscoe, H. K., and Wolff, E. W.: BrO, blizzards, and drivers of polar tropospheric ozone depletion events, Atmos. Chem. Phys., 9, 4639-4652, doi:10.5194/acp-94639-2009, 2009.

Kim, S., Huey, L. G., Stickel, R. E., Tanner, D. J., Crawford, J. H., Olson, J. R., Chen, G., Brune, W. H., Ren, X., Lesher, R., Wooldridge, P. J., Bertram, T. H., Perring, A., Cohen, R. C., Lefer, B. L., Shetter, R. E., Avery, M., Diskin, G., and Sokolik, I.: Measurement of $\mathrm{HO}_{2} \mathrm{NO}_{2}$ in the free troposphere during the intercontinental chemical transport experiment - North America 2004, J. Geophys. Res.-Atmos., 112, D12S01, doi:10.1029/2006jd007676, 2007.

Kühl, S., Pukite, J., Deutschmann, T., Platt, U., and Wagner, T.: SCIAMACHY limb measurements of $\mathrm{NO}_{2}, \mathrm{BrO}$ and OClO.
Retrieval of vertical profiles: Algorithm, first results, sensitivity and comparison studies, Adv. Space Res., 42, 1747-1764, doi:10.1016/j.asr.2007.10.022, 2008.

Kurosu, T. and Chance, K.: OMBRO Readme file, http://www.cfa.harvard.edu/ tkurosu/SatelliteInstrume-nts/ OMI/PGEReleases/index.html, 2011.

Liao, J., Sihler, H., Huey, L. G., Neuman, J. A., Tanner, D. J., Friess, U., Platt, U., Flocke, F. M., Orlando, J. J., Shepson, P. B., Beine, H. J., Weinheimer, A. J., Sjostedt, S. J., Nowak, J. B., Knapp, D. J., Staebler, R. M., Zheng, W., Sander, R., Hall, S. R., and Ullmann, K.: A comparison of Arctic BrO measurements by chemical ionization mass spectrometry and long path-differential optical absorption spectroscopy, J. Geophys. Res.-Atmos., 116, D00R02, doi:10.1029/2010jd014788, 2011a.

Liao, J., Huey, L.G., Tanner, D. J., Flocke, F. M., Orlando, J. J., Neuman, J.A., Nowak, J. B., Weinheimer A. J., Hall, S. R., Smith, J. N., Fried, A., Staebler, R. M., Wang, Y., Koo, J.-H., Cantrell, C. A., Weibring, P., Walega, J., Knapp, D. J., Shepson, P. B., and Stephens, C, R: Observations of inorganic bromine ( $\mathrm{HOBr}, \mathrm{BrO}$, and $\mathrm{Br}_{2}$ ) speciation at Barrow, $\mathrm{AK}$ in spring 2009 , J. Geophys. Res, in review, 2011 b.

Lindberg, S. E., Brooks, S., Lin, C. J., Scott, K. J., Landis, M. S., Stevens, R. K., Goodsite, M., and Richter, A.: Dynamic oxidation of gaseous mercury in the Arctic troposphere at polar sunrise, Environ. Sci. Technol., 36, 1245-1256, doi:10.1021/es0111941, 2002.

McConnell, J. C., Henderson, G. S., Barrie, L., Bottenheim, J., Niki, H., Langford, C. H., and Templeton, E. M. J.: Photochemical bromine production implicated in Arctic boundary-layer ozone depletion, Nature, 355, 150-152, 1992.

Neuman, J. A., Nowak, J. B., Huey, L. G., Burkholder, J. B., Dibb, J. E., Holloway, J. S., Liao, J., Peischl, J., Roberts, J. M., Ryerson, T. B., Scheuer, E., Stark, H., Stickel, R. E., Tanner, D. J., and Weinheimer, A.: Bromine measurements in ozone depleted air over the Arctic Ocean, Atmos. Chem. Phys., 10, 6503-6514, doi:10.5194/acp-10-6503-2010, 2010.

Oltmans, S. J.: Surface ozone measurements in clean-air, J. Geophys. Res.-Ocean. Atmos., 86, 1174-1180, 1981.

Ridley, B. A., Atlas, E. L., Montzka, D. D., Browell, E. V., Cantrell, C. A., Blake, D. R., Blake, N. J., Cinquini, L., Coffey, M. T., Emmons, L. K., Cohen, R. C., DeYoung, R. J., Dibb, J. E., Eisele, F. L., Flocke, F. M., Fried, A., Grahek, F. E., Grant, W. B., Hair, J. W., Hannigan, J. W., Heikes, B. J., Lefer, B. L., Mauldin, R. L., Moody, J. L., Shetter, R. E., Snow, J. A., Talbot, R. W., Thornton, J. A., Walega, J. G., Weinheimer, A. J., Wert, B. P., and Wimmers, A. J.: Ozone depletion events observed in the high latitude surface layer during the TOPSE aircraft program, J. Geophys. Res.-Atmos., 108, 8356, doi:10.1029/2001jd001507, 2003.

Rienecker, M. M, Suarez, M. J, Todling, R., Bacmeister, J., Takacs, L., Liu, H. C, Gu, W., Sienkiewicz, M., Koster, R. D, and Gelaro, R.: The GEOS-5 data assimilation system - Documentation of versions 5.0.1, 5.1.0, and 5.2.0. NASA Tech. Memo. 2007104606, vol. 27, edited by: Suarez, M. J., NASA, Hanover, MD, USA, 2007.

Salawitch, R. J., Canty, T., Kurosu, T., Chance, K., Liang, Q., da Silva, A., Pawson, S., Nielsen, J. E., Rodriguez, J. M., Bhartia, P. K., Liu, X., Huey, L. G., Liao, J., Stickel, R. E., Tanner, D. J., Dibb, J. E., Simpson, W. R., Donohoue, D., Weinheimer, A., Flocke, F., Knapp, D., Montzka, D., Neuman, J. A., Nowak, J. B., 
Ryerson, T. B., Oltmans, S., Blake, D. R., Atlas, E. L., Kinnison, D. E., Tilmes, S., Pan, L. L., Hendrick, F., Van Roozendael, M., Kreher, K., Johnston, P. V., Gao, R. S., Johnson, B., Bui, T. P., Chen, G., Pierce, R. B., Crawford, J. H., and Jacob, D. J.: A new interpretation of total column $\mathrm{BrO}$ during Arctic spring, Geophys. Res. Lett., 37, L21805, doi:10.1029/2010g1043798, 2010.

Scheuer, E., Talbot, R. W., Dibb, J. E., Seid, G. K., DeBell, L., and Lefer, B.: Seasonal distributions of fine aerosol sulfate in the North American Arctic basin during TOPSE, J. Geophys. Res.Atmos., 108, 8370, doi:10.1029/2001jd001364, 2003.

Scheuer, E., Dibb, J. E., Twohy, C., Rogers, D. C., Heymsfield, A. J., and Bansemer, A.: Evidence of nitric acid uptake in warm cirrus anvil clouds during the NASA TC4 campaign, J. Geophys. Res.-Atmos., 115, D00J03, doi:10.1029/2009jd012716, 2010.

Shetter, R. E. and Müller, M.: Photolysis frequency measurements using actinic flux spectroradiometry during the PEM-Tropics mission: Instrumentation description and some results, J. Geophys. Res.-Atmos., 104, 5647-5661, doi:10.1029/98jd01381, 1999.

Simpson, W. R., von Glasow, R., Riedel, K., Anderson, P., Ariya, P., Bottenheim, J., Burrows, J., Carpenter, L. J., Friess, U., Goodsite, M. E., Heard, D., Hutterli, M., Jacobi, H. W., Kaleschke, L., Neff, B., Plane, J., Platt, U., Richter, A., Roscoe, H., Sander, R., Shepson, P., Sodeau, J., Steffen, A., Wagner, T., and Wolff, E.: Halogens and their role in polar boundary-layer ozone depletion, Atmos. Chem. Phys., 7, 4375-4418, doi:10.5194/acp-74375-2007, 2007.

Slusher, D. L., Huey, L. G., Tanner, D. J., Flocke, F. M., and Roberts, J. M.: A thermal dissociation-chemical ionization mass spectrometry (TD-CIMS) technique for the simultaneous measurement of peroxyacyl nitrates and dinitrogen pentoxide, J. Geophys. Res.-Atmos., 109, D19315, doi:10.1029/2004jd004670, 2004.

Spurr, R. J. D., Kurosu, T. P., and Chance, K.: A linearized discrete ordinate radiative transfer model for atmospheric remote sensing retrieval, J. Quant. Spectrosc. Radiat. Transfer, 68, 689-735, 2001.
Theys, N., Van Roozendael, M., Errera, Q., Hendrick, F., Daerden, F., Chabrillat, S., Dorf, M., Pfeilsticker, K., Rozanov, A., Lotz, W., Burrows, J. P., Lambert, J. C., Goutail, F., Roscoe, H. K., and De Maziere, M.: A global stratospheric bromine monoxide climatology based on the BASCOE chemical transport model, Atmos. Chem. Phys., 9, 831-848, doi:10.5194/acp-9-831-2009, 2009.

Theys, N., Van Roozendael, M., Hendrick, F., Yang, X., De Smedt, I., Richter, A., Begoin, M., Errera, Q., Johnston, P. V., Kreher, K., and De Maziere, M.: Global observations of tropospheric BrO columns using GOME-2 satellite data, Atmos. Chem. Phys., 11, 1791-1811, doi:10.5194/acp-11-1791-2011, 2011.

Weibring, P., Richter, D., Fried, A., Walega, J. G., and Dyroff, C.: Ultra-high-precision mid-IR spectrometer II: system description and spectroscopic performance, Appl. Phys. B, 85, 207-218, doi:10.1007/s00340-006-2300-4, 2006.

Weinheimer, A. J., Montzka, D. D., Campos, T. L., Walega, J. G., Ridley, B. A., Donnelly, S. G., Keim, E. R., Del Negro, L. A., Proffitt, M. H., Margitan, J. J., Boering, K. A., Andrews, A. E., Daube, B. C., Wofsy, S. C., Anderson, B. E., Collins, J. E., Sachse, G. W., Vay, S. A., Elkins, J. W., Wamsley, P. R., Atlas, E. L., Flocke, F., Schauffler, S., Webster, C. R., May, R. D., Loewenstein, M., Podolske, J. R., Bui, T. P., Chan, K. R., Bowen, S. W., Schoeberl, M. R., Lait, L. R., and Newman, P. A.: Comparison between DC-8 and ER-2 species measurements in the tropical middle troposphere: $\mathrm{NO}, \mathrm{NO}_{\mathrm{y}}, \mathrm{O}_{3}, \mathrm{CO}_{2}$, $\mathrm{CH}_{4}$, and $\mathrm{N}_{2} \mathrm{O}$, J. Geophys. Res.-Atmos., 103, 22087-22096, 10.1029/98jd01421, 1998.

Zeng, T., Wang, Y. H., Chance, K., Browell, E. V., Ridley, B. A., and Atlas, E. L.: Widespread persistent near-surface ozone depletion at northern high latitudes in spring, Geophys. Res. Lett., 30, 2298, doi:10.1029/2003g1018587, 2003. 